2000

\title{
Credibility, Agency, and the Interaction Order
}

Philip Manning

Cleveland State University, p.manning@csuohio.edu

Follow this and additional works at: https://engagedscholarship.csuohio.edu/clsoc_crim_facpub

Part of the Sociology Commons

How does access to this work benefit you? Let us know!

\section{Publisher's Statement}

Published as Manning, Philip. 2000. "Credibility, Agency, and the Interaction Order." Symbolic

Interaction 23(3):283-297. (C) 2000 by the Society for the Study of Symbolic Interaction. Copying and permissions notice: Authorization to copy this content beyond fair use (as specified in Sections 107 and 108 of the U. S. Copyright Law) for internal or personal use, or the internal or personal use of specific clients, is granted on behalf of Society for the Study of Symbolic Interaction for libraries and other users, provided that they are registered with and pay the specified fee via Rightslink® on JSTOR (http://www.jstor.org/r/ucal) or directly with the Copyright Clearance Center, http://www.copyright.com.

\section{Original Citation}

Manning, Philip. 2000. "Credibility, Agency, and the Interaction Order." Symbolic Interaction 23(3):283-297.

\section{Repository Citation}

Manning, Philip, "Credibility, Agency, and the Interaction Order" (2000). Sociology \& Criminology Faculty Publications. 11.

https://engagedscholarship.csuohio.edu/clsoc_crim_facpub/11

This Article is brought to you for free and open access by the Sociology \& Criminology Department at EngagedScholarship@CSU. It has been accepted for inclusion in Sociology \& Criminology Faculty Publications by an authorized administrator of EngagedScholarship@CSU. For more information, please contact library.es@csuohio.edu. 


\title{
Credibility, Agency, and the Interaction Order
}

\author{
Philip Manning \\ Cleveland State University
}

\begin{abstract}
There are two ways of reading Goffman-as a theorist of trust and ritual accommodation, that is, as a theorist of the interaction order, or as a theorist of deception. I suggest a way of making these two readings compatible, by arguing that Coffman was interested in what I call the "production of credibility." Credibility is the quality of being believable, and this quality is integral to both trust and deception. Viewed in this way, Goffman explored the ways in which people make their actions convincing to other people. Although Coffman's analysis of the interaction order did not need a theory of the self, his work actually contains two quite different theories of the self: one linked to role analysis, one to his analysis of mental illness. I argue for the latter at the expense of the former. I conclude that Goffman both initiated substantive work about the interaction order and contributed to a synthesis of a theory of the interaction order and a theory of the self.
\end{abstract}

Despite the many illustrations, telling examples, and subtle observations, Goffman was an abstract thinker who sought to expose the most general characteristics of face-to-face interaction. As he stated in his Presidential Address, the analysis of face-to-face interaction is as much an abstraction as the "behavior" of corporations or New York crime statistics (1983b:9). Goffman uses all examples to serve his classificatory schemes. If his examples are stripped away, then what remains is an account of the micro-sociological world with a high level of abstraction. This is quite clear in The Presentation of Self in Everyday Life (1959), in the preface of which Goffman himself described the book as outlining a general framework, with the result that much of it is "necessarily abstract." However, it is also true that even his ethnographic studies were abstract and self-consciously theoretical. For example, Asylums (1961) is sometimes poorly understood as simply a case study of St. Elizabeth's hospital in the 1950s. Actually, it is an ethnography of the concept of the total institution (Manning 1992:17-18; 1999b). As such, it very generally extends ideas Goffman derived from some of Everett Hughes's lectures at the University of Chicago (Burns 1992). Part of Goffman's skill lay in integrating a suggestive vocabulary and 
persuasive examples into elaborate and necessarily abstract theoretical classifications.

Goffman liked to masquerade as someone who knew next to nothing about the abstract world of social theory, which he sometimes portrayed as part of the alien world of European sociology and hence literally and metaphorically miles away from his Canadian and American background. Wrong has tried to warn us against any tendency to minimize Goffman's theoretical sophistication:

Goffman stories are legion among those who knew him at all well, although mine go back farther than just about anyone else's. I shall confine myself to a few recollections about his intellectual outlook. The widespread notion that Erving was an inspired naif, a novelist manqué with unusual powers of social observation, is utterly wrong. He already had an acute and far-ranging theoretical mind when I met him [in Toronto]. (1990:9)

Wrong points out here that Goffman was clearly knowledgeable about European social theory before he began his graduate work at Chicago. He wrote his dissertation (1953) - at least in part - in Paris, and it contains many references to existential debates of the 1950 s. ${ }^{1}$ He was similarly knowledgeable about French social theory in general, as writers who found an underlying structuralism in his work discovered, sometimes at their expense. Some of Goffman's papers and books also indicate his familiarity with philosophical issues, notably in the beginning of Frame Analysis (1974) and in the jokey title "Felicity's Condition" (1983a), which makes sense only in the context of the philosophy of not only Austin but also Wittgenstein, Grice, and Searle. Goffman had, in fact, participated in a seminar with Searle at Berkeley and, hence, learned part of the philosophical trade from the inside. It is instructive to note that Searle $(1995,1998)$ is now investigating some of the core issues in the philosophy of the social sciences, in part through a reading of, and in a sense a return to, George Herbert Mead.

\section{THE INTERACTION ORDER AND DECEPTION}

The most influential contemporary reading of Goffman's social theory portrays him as a theorist of the interaction order, of the ritual accommodation of face-to-face interaction (Drew and Wootten 1988; Giddens 1984, 1987). Goffman in fact coined the term "interaction order" in the conclusion of his dissertation (1953) and then highlighted its importance for him by recycling it as the title of his Presidential Address. In much the same way that each of Goffman's prefaces serves as a general introduction to a particular book, the Presidential Address is a preface and introduction to his work as a whole. Clearly, an important part of this introduction is his attempt to analyze the world of face-to-face interaction as a separate domain worthy of independent study. The interaction order consists of "systems of enabling conventions" that render public conduct orderly and predictable and is sustained by shared cognitive and normative presuppositions (Goffman 1983b:5-9). Sociologists can understand the interaction order in part through empathy and introspection, because the normative conventions of our day-to-day lives are "anchored" in sub- 
jective feelings that we not only share but which have been "worn smooth by constant repetition" (1983b:9).

Therefore, the very orderliness and interpretive accessibility of the interaction order suggests its viability as an independent domain for analysis. Many mundane tasks require tacit agreement about the ground rules of the interaction order. Consider some of the multiple and sometimes simultaneous tasks accomplished during face-to-face interaction: the preservation of efficient pedestrian traffic flow, the management of environments populated by strangers, and the achievement of shared understandings. Goffman (1983b:6) believed that these accomplishments are made possible by a set of "arrangements which allow a great diversity of projects and intents to be realized through unthinking recourse to procedural forms."

This way of reading his work typifies what I would like to call the "European Goffman" who, as Giddens (1987) puts it, is striving to be a "systematic social theorist." The European Goffman had almost Parsonian ambitions, aiming to be maximally inclusive in his account of the interaction order. Reading Goffman in this way makes his ideas compatible with Parsons's account of socialization and the internalization of norms as forms of social control (see Parsons 1951:297-321). Giddens (1984) integrated this Goffman into structuration theory and awarded Goffman an important role in his reconceptualization of the relationship between structure and agency. In Giddens's work, the European Goffman emerges as the principal theorist of "practical consciousness," that is, of the taken-for-granted, nondiscursive practices of everyday life (see especially Giddens 1984).

However, I want to suggest that an "American" Goffman has emerged as a controversial transitional figure between a Hughesian version of Chicago sociology and the emergence of ethnomethodology. ${ }^{2}$ The American Goffman did not, as Goffman (1983b:2) himself realized, overwhelm his colleagues by the strength of his arguments. On the contrary, he offended different groups in different ways. For Hughes, who had a well-documented strong dislike for social theory (see Fine 1995), Goffman had drifted into barren theoretical speculation and away from empirical work. Nevertheless, Goffman described himself as a "Hughesian urban ethnographer" (quoted in Verhoeven 1993:318), although he later added in the same interview: "I am really on that side, closer to the structural functionalists, like Parsons ${ }^{3}$ or Merton" (p. 324). Arguably, this ability to make creative use of the different influences of both symbolic interactionism and structural functionalism made Goffman's work powerful, and positioned him as one of the leading post-World War II American sociologists.

Many ethnomethodologists believed, however, that Goffman's work failed to analyze the complexities of the actual procedures used in day-to-day life. Ethnomethodologists often consider his descriptions to be too general to account for the complexity of naturally occurring social interaction (see, e.g., Schegloff 1988).

This rough-and-ready distinction between a European and an American Goffman might explain why no distinct Goffman school of sociology has emerged: his work can be read in different ways, producing diverse uses for his ideas. Alternative explanations for the lack of a Goffman school also exist; for example, he did not 
train many graduate students (Fine and Manning 2000) and was not always considerate to those whom he did (see Schegloff 1992). Nevertheless, a kind of Goffman school has emerged in the prolific ethnographic work of Gary Fine (see especially 1983, 1987, 1996), as well as Elijah Anderson (1978, 1990), Lyn Lofland (1998), Carol B. Gardner (1995), Spencer Cahill (1987; Cahill and Eggleston 1994), Greg Smith (1997), and others. All of these writers have extended Goffman's theoretical analysis of the interaction order, worked in ways similar to Goffman, and adhered to the same scholarly tradition.

More contemporary ethnographic studies of the kind that Fine, and recently Duneier (1992), championed are needed to show whether Goffman's largely urban analysis of the interaction order equally applies to contemporary suburban landscapes. These landscapes contain homogenized and often enclosed environments of shopping malls, sports arenas, and sequestered living spaces. Pedestrian traffic flow-the locus of civil inattention-is no longer primarily urban and outside. In fact, there are many communities without sidewalks. Rather, the baseline case of pedestrian traffic flow now probably occurs in the mall and the arena. Lofland's (1998) most recent work provides an important step toward answering this question. She has identified five key characteristics of social interaction: cooperative motility, civil inattention, audience role prominence, restrained helpfulness, and civility toward diversity pinpoint elements that are particularly applicable to the suburban environments of shopping malls, theme parks, and sports arenas (see esp. pp. 25-34). ${ }^{4}$

Although it has limitations, the "European" reading of Goffman as principally a theorist of the interaction order offers a useful way of highlighting part of his contribution to sociological thinking. By contrast, the "American" reading of Goffman raises a different but also important set of issues concerning his relationship to both symbolic interactionism and Hughes (see Jaworski 2000) and to ethnomethodology and Garfinkel. Giddens's reading assumes that Goffman's ideas are easily compatible with Garfinkel's. We need to examine this assumption carefully. Although both Goffman and Garfinkel are "micro" sociologists (but see Schegloff 1990 for a discussion of this), their approaches differ. Garfinkel's Wittgensteinian emphasis on the elucidation of social practices as contingent achievements seems to preclude the attempt at systematic social theory that Giddens (1987) identified in Goffman's work.

However, a substantive problem arises with the view of Goffman as primarily a theorist of the interaction order: much of his work did not, directly at least, address the interaction order, trust, or ritual accommodation. Rather, Goffman's works analyzed deception and thus contributed to what Ricoeur (1970:30) called the "hermeneutics of suspicion." Lyman and Scott (1970:29-70) have written extensively about the connection between game theory and deception in Goffman's sociology. Goffman's first published papers initiated his long-term interest in deception. "Symbols of Class Status" (1951) analyzed the ways in which symbols can be misused, and "On Cooling the Mark Out" (1952) analyzed all social situations as confidence tricks.

In the "Symbols" paper, Goffman argued that because class symbols represent a "complex of social qualifications" (p. 126) that are often hard to substantiate, they 
are particularly vulnerable to misuse. As a result, legitimate status holders seek to find ways to authenticate and hence protect the symbols they rely on to distinguish bona fide members of their group from imposters. Goffman outlined six devices that are intended to prevent a person from misrepresenting his or her class (pp. 297-301). He also described the role of "curator groups" in the maintenance of the "machinery" of status. However, as Goffman emphasized, the very devices used to maintain class symbols can be used by imposters. As a result, the "circulation of symbols" (p. 303) cannot be stopped and a "sign which is expressive for the class in which it originates comes to be employed by a different class-a class for which the symbol can signify status but ill express it" (p. 304).

Deception is also integral, of course, to the world of the confidence trickster that Goffman explored in "On Cooling the Mark Out" (1952). This paper attempts to take the structure of the confidence trick and show that it can be applied to any situation in which a person suffers a loss of status. In this sense, the paper constitutes an introduction to the sociology of failure. The "mark" is robbed of something and in return is given "instruction in the philosophy of taking a loss" (p. 452).

The theme of deception is at the center of The Presentation of Self in Everyday Life, a book that could have easily and perhaps more appropriately been called The Misrepresentation of Self in Everyday Life. The dramaturgical vocabulary developed by Goffman concerning "impression management" offers a framework with which to understand the types and components of deception. The Presentation of Self is in a sense a textbook of deception. Thus, the chapter "Performances" describes techniques for the "dramatic realization" of manipulative presentations of self that actors build out of impressions and fronts that they design to mislead. Goffman (1959:40) illustrated this performance, using, among others, the example of a baseball umpire who must make his decisions immediately in order to give the impression of certainty, thereby forgoing the moment he needs to confirm his judgments to himself.

What is true of the individual performer is also true of the team. "The definition of the situation projected by a particular participant is an integral part of a projection that is fostered and sustained by the intimate cooperation of more than one participant" (1959:83).

This definition of the situation gives every team the "character of a secret society" in which their members all share the "sweet guilt of conspirators" (1959:108). This conspiracy is confirmed in the back regions away from public view where the team members' front stage performances are "knowingly contradicted" (1959:114).

Dramaturgical deception requires more than impression management; performers must also show "dramaturgical discipline."

It is crucial for the maintenance of the team's performance that each member of the team possess dramaturgical discipline and exercise it in presenting his own part. I refer to the fact that while the performer is ostensibly immersed and given over to the activity he is performing, and is apparently engrossed in his ac- 
tions in a spontaneous, uncalculating way, he must none the less be effectively dissociated from his presentation in a way that leaves him free to cope with dramaturgical contingencies as they arise. He must offer a show of intellectual and emotional involvement in the activity he is presenting, but must keep himself from actually being carried away by his own show lest this destroy his involvement in the task of putting on a successful performance. (1959:210)

In his early work, then, Goffman developed an analysis and a vocabulary of the ways in which people are able to mislead others by manipulating their assumptions about appearance and reality.

Goffman's analysis of deception is also evident in his various analyses of industrial spies, espionage agents, and rational choice dilemmas, all of which are prominent in Encounters (1961b) and Strategic Interaction (1969) (a phrase he preferred to "symbolic interaction"). The essay "Expression Games," in the latter of these books, contains what is in effect Goffman's basic theory of deception. The essay ends with a justification for Goffman's strong interest in the espionage world:

In every social situation we can find a sense in which one participant will be an observer with something to gain from asserting expressions, and another will be a subject with something to gain from manipulating the process. A single structure of contingencies can be found in this regard which renders agents a little like us all and all of us a little like agents. (1969:81)

Goffman drew this conclusion from his account of the basic moves involved in deception and counterdeception. These basic moves include the "unwitting," the "naïve," the "covering," the "uncovering," and finally the "counter-uncovering" move (1969:11-27). They can be understood as a "set of tricky ways of sympathetically taking the other into consideration as someone who assesses the environment and might profitably be led into a wrong assessment" (1969:13).

Later, in Frame Analysis, Goffman offered a theory of deception that combined these game-theory ideas with his dramaturgical perspective. In that work Goffman defined deception as consisting of the work done to ensure that "incorrect assumptions are initially made" (1974:440). In a manner reminiscent of The Presentation of Self, Frame Analysis contains a structural and almost textbook-like account of the resources available to those wishing to deceive.

The key to Goffman's frame analysis is his belief that however we convince others that we are as we appear to be, we use the same resources confidence tricksters use to deceive people: "[W]hatever we use as a means of checking up on claims provides a detailed recipe for those inclined to cook up reality" (1974:445).

Goffman's idea that we "cook up reality" reconciles the apparent differences between his analyses of trust and deception by showing that both make use of the same mechanisms to succeed. The same resources we used to appear trustworthy are the ones we use for betrayal. Goffman was not, therefore, primarily interested in trust, ritual accommodation, or deception; rather, he focused on developing a theory of credibility. In short, Goffman analyzed the ways in which people make their performances convincingly real. 
A good test case for the possibility of analyzing how we make ourselves and our social settings convincingly real is interaction among the unacquainted. This setting might be simple enough to find a parsimonious account of the rules necessary to maintaining a sense that everything is as expected, that is, that "nothing" is really taking place. Thus children, comedians, and the mentally ill are so useful to sociologists: their lives reveal what Garfinkel (1967) called "breaching experiments" in that their behavior consistently involves rule violations. In these groups, often "something" (rather than the desired "nothing") is taking place, and the something is often disruptive, tiring, or embarrassing to someone present. Because of this, children, comedians, and the mentally ill, among others, teach us by default what has to occur for people and social situations to be, or at least to appear, convincingly real. In this sense, Goffman's work attempted to understand the resources by which we maintain a shared sense of what the world is like.

\section{TENSIONS IN GOFFMAN'S ACCOUNT OF THE SELF 5}

The danger in focusing on the ways in which people sustain a credible world is that the people themselves begin to appear hollow. For the most part, Goffman provided us with a model of the structure of social interaction, not a model of the performing agent. For example, The Presentation of Self in Everyday Life indicates a lot about the presentation of self and not much about the self. As Wrong (1998:223) argues, Goffman and most symbolic interactionists fail to offer a convincing account of what motivates people to do what they do. Prager (1998:70) makes a similar point when he suggests that a sociological focus on ritual deflects attention away from the analysis of the "interpreting self."

Several commentators have recognized that Goffman often avoided analyzing the "inner world," or mental life, of people in favor of the structure of social interaction. Lyman and Scott (1975:107) state it well when they suggest that in The Presentation of Self, Goffman "moved the theater of performances out of the 'head' and into public places." More recently, Williams (1998:154) describes Goffman's position eloquently:

He [Goffman] wanted to provide what he regarded as a distinctly sociological account of the person. In doing this, he treated as irrelevant the large variety of ways that people think about their own or other people's "inner lives." He was not concerned with individuals in the way that psychologists or novelists are when they attempt to display the full depth of human motivation, feeling, intention, unconsciousness and so on.... To understand the self sociologically it had to be approached as a social institution, and researched by observing and analyzing externally observable forms of conduct. ${ }^{6}$

In the Verhoeven interview, Goffman was unusually candid about his analysis of the self, describing his research in a way that confirms the assessments by Lyman and Scott, Williams, Wrong, and Prager:

What I'm doing is the structural Social Psychology that is required, or is natural for, Sociology. That is, given Sociology is a central thrust, what can it say about 
the individual? Not that the individual is the central unit that permits us to study society; but if you take society as the basic and substantive unit ... what is it we have to assume about individuals, so that they can be used or be usable socially? ... I am an ethnographer of small entities. (1993:322-23)

He added later:

[S]ociologists in some ways have always believed in the social construction of reality. The issue is, at what level is the reality socially constructed? ... But where I differ from social constructionists is that I don't think the individual himself or herself does much of the constructing. (1993:324)

This passage suggests that Goffman deliberately downplayed the importance of analyzing the interpreting self in favor of an analysis of the interpreted self. A more skillfully worded version of this idea can be found in the frequently cited introduction to Interaction Ritual:

I assume that the proper study of interaction is not the individual and his psychology, but rather the syntactical relations among the acts of different persons mutually present to one another.... What minimal model of the actor is needed if we are to wind him up, stick him in amongst his fellows, and have an orderly traffic of behavior emerge? ...

Not, then, men and their moments. Rather moments and their men. (1967:2-3)

However, as I will suggest, this "minimal model" strategy is largely reversed in his investigations of the behavior of the mentally ill, in which a more elaborate analysis of the self emerges.

Although Goffman wrote extensively about deceiving others, he wrote almost nothing about self-deception. Perhaps this omission is tacitly acknowledged by his allusion to Freud's The Psychopathology of Everyday Life (1956) in the title of his own The Presentation of Self in Everyday Life. Insofar as Freud was the leading theorist of self-deception, perhaps Goffman saw his own work as complementing rather than competing with Freud's psychoanalytic investigations. Some evidence exists for this claim. Wrong recalls:

Once he [Goffman] defended Freud's emphasis on the body and the priority of infant experience against the more congenial neo-Freudian culturalists we favored. His later antipathy to psychoanalysis is well known, but he created in me the first small twinge of doubt as to whether there was not more truth and profundity in the vision of the founder than in all the Erich Fromms, Karen Horneys, and Gordon Allports who were so ready to revise him. (1990:9)

According to Wrong, at least in the early 1950s Goffman not only knew about Freud but also willingly defended psychoanalytic claims. However, it is also true, as Wrong also indicates above, that the tone of Goffman's published comments about psychoanalysis ranges mainly from the critical to the hostile, although these wellinformed comments indicated his extensive psychoanalytic knowledge. ${ }^{7}$

Nonetheless, any appeal to complementarity between Freud's analysis of selfdeception and Goffman's analysis of deception is fraught with difficulty. Every dis- 
cussion of deception implies the promise of a knowable world. This implication makes detective and spy stories appealing: at the end everything is explained and fits neatly into place. By contrast, Freud's analysis of self-deception only promises to reveal fragments of an unknowable world and an unknowable self. Psychoanalysis can only partially recover unconscious wishes. At one point, Freud (1926) likened psychoanalysis to the recovery of flooded land: the role of the analyst is to push the water, the id, back as far as possible, thus preserving as much of the self as possible for the ego. But the project is only ever partial and temporary.

Goffman's preference for theoretical abstraction, although well hidden amid revealing examples, made it difficult for him to offer an adequate theory of selfhood. He made tremendous progress in understanding the resources used by people to preserve or manipulate a shared sense of what is taking place, but he did so at the expense of a viable account of the people who use these resources. Goffman's roleanalytic account places the self in danger of collapsing into its roles. It becomes, in an infamous phrase, a peg on which something can be put for a while. In this sense, Goffman offers us something quite different from Freud.

The secondary literature contains important and in many ways consistent criticisms of Goffman's account of the self. The model of the self in The Presentation of Self and the chapter "Role Distance" in Encounters (1961b) suggests that our public performances are all that we are. Nothing underlies these performances, except perhaps a necessary fiction of a unified self. But Goffman suggests that it is just a fiction. He presents a radically de-personalized world in which we are simultaneously performer and audience: we hear our own disembodied voices as disembedded cries, and we watch ourselves perform in a frightening version of the looking glass self.

In one sense, these criticisms are misplaced. Goffman's analysis of the interaction order does not require a theory of the self, as his main focus concerned the ground rules or enabling conventions that people use in daily life. $\mathrm{He}$ analyzed the resources people use in managing daily living rather than the people who use them. Because the interaction order analyzes the structure of group life, it remains separate from the individual members of groups. This argument is recognizably Durkheimian and one that Goffman himself might readily have accepted as a reasonable account of both sociology in general and his own work in particular. Nevertheless, Goffman also succumbed at times to a theory of the self, or, more accurately, to different theories of the self.

His most criticized theory of the self arose out of his role analysis, where, in his attempt to integrate "role distance" into a distinctly sociological rather than psychological theory, he argued that actors play out selves in their different performances. For example, MacIntyre (1982:30) has complained that Goffman has "liquidated the self into its role-playing," adding that for Goffman the critical mistake is to "suppose that there is a substantial self over and beyond the complex presentations of role-playing" (p. 31). MacIntyre suggests that, for Goffman, the social world is "everything," permitting only a "ghostly ' $I$ " " with almost no selfhood (p. 31).

Jonathan Glover (1988) has also explored and criticized Goffman's role theory. 
Glover notes that Goffman's analysis suggests that "the things we do which seem to escape from social roles are themselves refinements to these roles" (1988:171). In response, Glover claims:

Of course we are shaped by people's expectations of us, and of course these vary with our job, our sex, our age, and so on. But it is an illusion to think that we are utterly malleable, submitting entirely to social molding. This picture might fit people who had no inner story. They would have no conception of themselves apart from the conception other people had. They would lack desires and values in the light of which to criticize the demands made of them, and would have no independent views about how their story should continue. We ar not such people. (1988:175)

Glover's suggestion that Goffman's model of the person implies someone who has no "inner story" connects with MacIntyre's (1982:108-10) sense that Goffman's world is amoral. It also resonates with Sennett's (1970:36) belief that Goffman describes a two-dimensional world in which there are scenes but no plots.

Frame Analysis contains a description of the self that is quite compatible with these critical readings. Here, Goffman suggested that we all endeavor to understand people using what he calls a "tacit theory of expression" (1974:462). This theory assumes that there are things such as relationships, feelings, and character, and that they are revealed in various ways. Goffman, however, implies that this theory is quite wrong. Instead he suggests that all we have are just "expressions and gestural equipment" for providing certain kinds of displays-and this equipment can easily be used either to convey genuine feeling or to deceive.

Although this tacit model of the self runs through much of his work, Goffman also used another, more suggestive model that is compatible with Glover's insistence that we have an "inner story." This second model of the self is prominent in Goffman's writings about both the nature of mental illness and the institutionalization and treatment of the mentally ill. Although Asylums contains his most sustained investigation of these topics, Goffman investigated and wrote about mental illness throughout his career (Gronfein 1999; Manning 1999a). Perhaps Goffman's most poignant paper is "The Insanity of Place" (1971, in Relations in Public) in which, in his characteristically neutral tone, he described the difficulties of living with someone who is mentally ill, in a thinly veiled reference to his own experiences with his first wife. ${ }^{8}$

In Asylums, Goffman is often anxious to promote the idea that patients in mental hospitals act in ways similar to inmates in a variety of total institutions. In Asylums and elsewhere, he suggests that psychiatrists often misidentify the resourceful ways in which their patients adapt to the threatening experience of the hospital as symptoms of underlying illness. In his most direct analysis of this issue, Goffman (1963:21641) argues that psychiatrists need but don't have a way of distinguishing symptomatic from nonsymptomatic situational improprieties. Without this distinction, the psychiatrist can misidentify a "secondary adjustment" as a medical symptom.

Elsewhere (1999a) I have argued that significant aspects of Goffman's analysis of 
mental illness contain what Woolgar and Pawluch (1985) call "ontological gerrymandering." This is because Goffman frequently (albeit tacitly) claimed to analyze mental illness from a privileged space from which he could see mental illness as it "really" is. This implies that his understanding of mental illness exceeds that of the psychiatric profession, but he does not explain why his view of mental illness supersedes prevailing medical doctrine. Arguably, Goffman's advocacy (even if misplaced) of a "super psychiatry" (Manning 1999a:98) shows the strength of his belief in an ethnography-based sociology.

Despite doubts about some of Goffman's arguments concerning mental illness, they contain a much richer implicit theory of selfhood than the one embedded in his analysis of roles. His analysis of "secondary adjustments" particularly reveals its potential. To theorize the role of secondary adjustments in all total institutions, Goffman had to incorporate an elaborate theory of the self that could show how inmates draw on inner resources to withstand oppressive institutional conditions. The third essay of Asylums is a long and often poignant tribute to the many ways inmates find to preserve their integrity and sense of worth. Ironically, then, to criticize what he saw as the paucity of orthodox psychiatry's account of the self, Goffman had to develop a more sophisticated theory than many of his role-theoretic formulations allowed.

My earlier characterization of Goffman's analysis of the interaction order as an analysis of the conditions of credibility gives us a way of understanding how Goffman could slip into a theory in which the self has been liquidated. What is credible may or may not be true: Goffman was primarily interested in the resources whereby something can be made to seem true. Insofar as Goffman focused on these resources, the person is likely to appear-by default—as a cynical manipulator of impressions.

\section{THEORETICAL AND SUBSTANTIVE DEVELOPMENT OF GOFFMAN'S IDEAS}

In this article, I have advocated a reading of Goffman that suggests that his ideas about the interaction order and deception converge into an analysis of the production and reproduction of credibility. Maintaining credibility involves the use of various kinds of resources and a willingness to abide by rules of conduct. When the social world is credible it is "convincingly real," which, in the context of everyday behavior, often means that participants have a sense that "nothing" in particular is going on. That is, the setting and the people in it appear unremarkable, in the sense of not being worthy of a remark. I have also suggested that interaction among the unacquainted is not only a substantive topic in its own right but also a test case for the ability of sociological analysis to describe the rules and resources underlying a relatively simple and frequently occurring social practice. It is relatively simple in the sense that managing a stranger in a shopping mall should be simpler than, for example, managing a friendship that has not just a present but also a history and a projected future.

For the most part, Goffman's work contains a sustained attempt to analyze what 
he called the enabling conventions of the interaction order, or what I have described as the conditions of credibility. Goffman wanted to show that the interaction order is an autonomous realm that can be analyzed separately and in its own terms. Described in this way, Goffman did not need a theory of the self.

However, Goffman discovered that he needed a theory of the self when he analyzed aspects of mental illness and institutionalization. Thus, Asylums and related papers differ theoretically from his general analyses of face-to-face interaction, in that they contain a potentially viable theory of the self. Goffman needed this theory so that he could investigate what might be called the inmates' "strategies of resistance" embedded in various secondary adjustments. To further his account of the behavior of patients at St. Elizabeth's Goffman had to draw on what he often rejected, namely, a theory of an "inner core" to the self that is expressed in various performances and which stretches between them.

Goffman's analysis in Asylums is so compelling because it finally contains both "scenes" and a "plot," to replay Sennett's comment on Goffman. Asylums also displays a rich qualitative methodology: I have described this as an "ethnography of concepts." Perhaps, then, Goffman's social theory can be further developed by linking his analysis of the interaction order to the theory of the self, found in his writings about mental illness. I take this to be one of the directions of Giddens's structuration project. Giddens's specific contribution to our understanding of interpretive sociology has initiated what Turner $(1988 ; 46-49)$ has called a "psychoanalytic sociology." This approach points toward an integration of symbolic interactionism and a version of psychoanalytic ideas that Harry Stack Sullivan and others first proposed in the 1920 s and 1930s. The "qualitative," nonexperimental, hermeneutic, case study approach of psychoanalysis promised then to be and perhaps still is compatible with many of the assumptions underlying symbolic interactionism. Giddens's contemporary synthesis is more sophisticated than anything imagined by Chicago sociologists and psychiatrists of the 1920s and 1930s, as it is grounded in both the "objectrelations" school of psychoanalysis and the American pragmatist tradition of Mead, Goffman, and Erikson. Giddens's work could usefully be combined with Chodorow's (1999) most recent writings on object relations.

The integration of an analysis of the interaction order and a sophisticated theory of the self offers a critical theoretical development to both Goffman's work and symbolic interactionism. It promises to provide a way of analyzing not only the enabling conventions of the interaction order but also the people who use them.

Acknowledgments: An earlier version of this article was presented at the 1999 Couch-Stone Symposium at the University of Nevada at Las Vegas in the session "Goffman Revisited." I would like to thank the three reviewers and the editor of Symbolic Interaction, Kathy Charmaz, for their helpful and detailed comments on the first draft. I have also benefited from discussions with Gary Jaworski, Greg Smith, and Yves Winkin. 


\section{NOTES}

1. Goffman also retained an interest in antiques throughout his life and enjoyed traveling to Europe on buying sprees (Marx 1984).

2. One of the most important readings of Goffman and his relationship to the ideas of both Chicago sociology and ethnomethodology remains Lyman and Scott's $A$ Sociology of the Absurd (1970).

3. For readers familiar only with what I am calling the American Goffman, the comparison with Parsons may seem mystifying. It is worth rereading the final essay of Asylums in which Goffman explicitly acknowledges his debt to Parsons.

4. Useful background information to Lofland's argument can be found in Ortiz (1994) and Sorkin (1992), particularly Crawford's fine paper.

5. One of the most detailed examinations of this tension remains the unpublished paper by Greg Smith (1999) of the University of Salford. See his "The Proprieties of Persondom: The Individual in the Writings of Erving Goffman" presented at the 1999 Couch-Stone Symposium.

6. In his paper, Williams (1998:155) distinguishes three accounts of the self in Goffman's work. His analysis could be usefully compared to the view I outline in this section.

7. It may also be worth adding that at Chicago Goffman was romantically involved with Elizabeth Bott (now Elizabeth Bott Spillius), who has since become a leading psychoanalyst.

8. For this and many other insights into Goffman's life and work, I am indebted to Yves Winkin.

\section{REFERENCES}

Anderson, Elijah. 1978. A Place on the Corner. Chicago: University of Chicago Press. 1990. Streetwise: Race, Class and Change in an Urban Community. Chicago: University of Chicago Press.

Bulmer, Martin. 1984. The Chicago School of Sociology. Chicago: University of Chicago Press.

Burns, Tom. 1992. Erving Goffman. London: Routledge.

Cahill, Spencer. 1987. "Children and Civility: Ceremonial Deviance and the Acquisition of Ritual Competence.” Social Psychology Quarterly 50:312-58. :

Cahill, Spencer and R. Eggleston. 1994. "Managing Emotions in Public: The Case of Wheelchair Users." Social Psychology Quarterly 57:300-12.

Crawford, Margaret. 1992. "The World in a Shopping Mall." In Variations on a Theme Park: The New American City and the End of Public Space, edited by M. Sorkin. New York: Farrar, Straus and Giroux.

Chodorow, Nancy. 1999. The Power of Feelings. New Haven: Yale University Press.

Ditton, Jason, ed. 1980. The View from Goffman. London: Macmillan.

Drew, Paul and Paul Wootten, eds. 1988. Erving Goffman: Exploring the Interaction Order. Cambridge: Polity.

Duneier, Mitchell. 1992. Slim's Table. Chicago: University of Chicago Press.

Fine, Gary. 1983. Shared Fantasy: Role-Playing Games as Social Worlds. Chicago: University of Chicago Press.

1987. With the Boys: Little League Baseball and Preadolescent Culture. Chicago: University of Chicago Press. 1996. Kitchens: The Culture of Restaurant Work. Berkeley: University of California Press.

Fine, Gary, ed. 1995. A Second Chicago School? Chicago: University of Chicago Press.

Fine, Gary and Philip Manning. 2000. "Erving Goffman." Pp. 457-85 in Blackwell Companion to Major Social Theorists, ed. G. Ritzer. Oxford: Blackwell..

Freud, Sigmund. 1926. "On the Question of Lay Analysis." In The Standard Edition of the Complete Psychological Works, edited and translated by J. Strachey et al. 24 vols. London: Hogarth Press. Vol. 20: 177-258.

- 1956. "The Psychopathology of Everyday Life." In The Standard Edition of the Complete 
Psychological Works, edited and translated by J. Strachey et al. 24 vols. London: Hogarth Press. Vol. 6.

Gardner, Carol B. 1995. Passing By: Gender and Public Harassment. Berkeley: University of California Press.

Garfinkel, Harold. 1967. Studies in Ethnomethodology. Englewood Cliffs, NJ: Prentice-Hall.

Giddens, Anthony. 1984. The Constitution of Society. Cambridge: Polity.

- 1987. Sociology and Modern Social Theory. Cambridge: Polity.

Glover, Jonathan. 1988. I: The Philosophy and Psychology of Personal Identity. London: Allen Lane, the Penguin Press.

Goffman, Erving. 1951. "Symbols of Class Status." British Journal of Sociology 11:294-304. . 1952. "On Cooling the Mark Out: Some Aspects of Adaptation to Failure." Psychiatry 15: 451-63.

1959. The Presentation of Self in Everyday Life. New York: Doubleday/Anchor.

1961a. Asylums. Harmondsworth: Penguin.

1961b. Encounters: Two Studies in the Sociology of Interaction. Indianapolis: Bobbs-Merrill.

1963. Behavior in Public Places: Notes on the Social Organization of Gatherings. New York: Free Press.

1967. Interaction Ritual: Essays on Face-to-Face Behavior. New York: Anchor.

1969. Strategic Interaction. Philadelphia: University of Pennsylvania Press.

1971. Relations in Public: Microstudies of the Public Order. New York: BasicBooks.

1974. Frame Analysis: An Essay on the Organization of Experience. New York: Harper and Row.

1983a. "Felicity's Condition." American Journal of Sociology 89:1-53.

1983b. "The Interaction Order." American Sociological Review 48:1-17.

Gronfein, William. 1999. "Sundered Selves: Mental Illness and the Interaction Order in the Work of Erving Goffman." Pp. 81-103 in Goffman and Social Organization: Studies in a Sociological Legacy, edited by G. Smith. London: Routledge.

Jaworski, Gary. 2000. "Erving Goffman: The Reluctant Apprentice." Symbolic Interaction 23:299_ 308

Lofland Lyn. 1998. The Public Realm: Exploring the City's Quintessential Social Territory. New York: Aldine de Gruyter.

Lyman, Stanford and M. Scott. 1970. A Sociology of the Absurd. New York: Meredith Corporation.

. 1975. The Drama of Social Reality. New York: Oxford University Press.

MacIntyre, Alistair. 1982. After Virtue: A Study in Moral Theory. London: Duckworth.

Manning, Philip. 1991. "Drama as Life: The Significance of Goffman's Changing Use of the Dramaturgical Metaphor." Sociological Theory 9:71-86. 1992. Erving Goffman and Modern Sociology. Stanford: Stanford University Press . 1998. "Procedure, Reflexivity and Social Constructionism." In The Politics of Constructivism, edited by I. Velody and R. Williams. London: Sage.

1999a. "The Institutionalization and Deinstitutionalization of the Mentally Ill: Lessons from Goffman." Pp. 89-104 in Counseling and the Therapeutic State, edited by J. Chriss. New York: Aldine de Gruyter.

1999b. "Ethnographic Coats and Tents." Pp. 104-18 in Goffman and Social Organization: Studies in a Sociological Legacy, edited by G. Smith. London: Routledge.

Marx, Gary. 1984. "Role Models and Role Distance: A Remembrance of Erving Goffman." Theory and Society 13: 649-62.

Ortiz, Steven. 1994. "Shopping for Sociability in the Mall." In Research in Community Sociology, edited by D. Chekki, S. Cahill, and L. Lofland. New York: JAI Press.

Parsons, Talcott. 1951. The Social System. New York: Free Press.

Prager, Jeffrey. 1998. Presenting the Past: Psychoanalysis and the Sociology of Remembering. Cambridge, MA: Harvard University Press.

Ricoeur, Paul. 1970. Freud and Philosophy: An Essay on Interpretation. New Haven: Yale University Press. 
Schegloff, Emanuel. 1988. "Goffman and the Analysis of Conversation." In Erving Goffman: Exploring the Interaction Order, edited by P. Drew and A. Wootten. Cambridge: Polity.

__ 1990. "Between Macro and Micro: Contexts and Other Connections." In The MicroMacro Link, edited by A. Jeffrey et al. Berkeley: University of California Press.

- 1992. Introduction to H. Sacks, Lectures on Conversation, edited by G. Jefferson. Oxford: Blackwell.

Searle, John. 1995. The Construction of Social Reality. New York: Free Press.

__. 1998. Mind, Language and Society. New York: BasicBooks.

Sennett, Richard. 1970. The Fall of Public Man. New York: Free Press.

Smith, Greg. 1997. "Incivil Attention and Everyday Intolerance: Vicissitudes of Exercising in Public Places." Perspectives on Social Problems 9:57-79.

—_- 1999. "The Proprieties of Persondom': The Individual in the Writings of Erving Goffman." Unpublished paper.

Smith, Greg, ed. Goffman and Social Organization: Studies in a Sociological Legacy. London: Routledge.

Sorkin, Michael, ed. 1992. Variations on a Theme Park: The New American City and the End of Public Space. New York: Farrar, Straus and Giroux.

Turner, Jonathan H. 1988. A Theory of Social Interaction. Stanford: Stanford University Press.

Verhoeven, Jef. 1993. "An Interview with Erving Goffman, 1980." Research on Language and Social Interaction 26:317-48.

Williams, Robin. 1998. "Erving Goffman." Pp. 151-62 in Key Sociological Thinkers, edited by R. Stones. New York: New York University Press.

Winkin. Yves. 1988. Erving Goffman: Les moments et leurs hommes. Paris: Minuit.

__ 1999. "What's in a Life Anyway?" Pp. 19-41 in Goffman and Social Organization, edited by G. Smith. London: Routledge.

- Forthcoming. Erving Goffman: A Biography. London: Macmillan.

Woolgar, Steve and Dorothy Pawluch. 1985. "Ontological Gerrymandering." Social Problems 32:214-27.

Wrong, Dennis. 1990. "Imagining the Real." In Authors of Their Own Lives, edited by B. Berger. Berkeley: University of California Press.

1998. The Modern Condition: Essays at Century's End. Stanford: Stanford University Press. 